\title{
The construction of knowledge in dentistry: the scientific production of three Brazilian magazines of 1990 to $2004^{*}$
}

\author{
Karla Patrícia Cardoso Amorim ${ }^{\mathrm{I}}$; Maria do Socorro Costa Feitosa Alves ${ }^{\mathrm{II}}$; Raimunda Medeiros \\ Germano ${ }^{\text {III }}$; Iris do Céu Clara Costa ${ }^{\text {IV }}$ \\ ${ }^{1}$ Professor, bioethic subject, specialization course, Associação Brasileira de Odontologia/ RN Section, \\ aeronautics dental surgeons, Natal, RN. <karlamorim@bol.com.br>; amorimkarla@yahoo.com.br

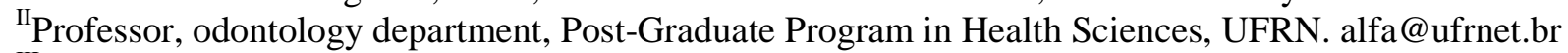 \\ III Professor, nursing department, vice-coordinator, Post-Graduate Program in Nursing, UFRN. \\ rgermano@natal.digi.com.br \\ ${ }^{I V}$ Professor, Post-Graduate Program in Health Sciences, coordinator, odontology graduation course, UFRN. \\ irisdoceu@dod.ufrn.br
}

\begin{abstract}
This paper aims to accomplish an analysis of the thematic approached by three dentistry Brazilian magazines, during the period of 1990 to 2004 . We start from the presupposed that these magazines play an important role in the professional formation, for they are dynamic means of divulgation of knowledge and, thus, they are going to influence and guide the thoughts, the reflections and the attitudes, molding the dentistry practice. We have articulated a quantitative approach, studying 2806 articles. The analysis of the empiric material tells us that different thematic and subjects have been published; therefore, some of them have predominated, while others have appeared more discretely. The five thematic that have been more often approached refer to the technical and professionalizing subjects, reaching 52,73\% of the publications. Amongst the conclusions, we point out that this research aims to contribute to the understanding of the knowledge construction process, granting reflection and after studies and also working as a parameter to follow the dentistry thinking.
\end{abstract}

Key words: scientific magazines, publications, dentistry, scientific knowledge

\section{INTRODUCTION}

Archaeologists have said that the writing art has its beginning in the middle of the fourth millennium BC, art that would change forever the nature of communication among human beings. Manguel (1997, p.206) reflects about the magic of writing, when has talked us since the first traces of pre-historic civilization, human society had tried to overcome the barriers of geography, the final nature of

\footnotetext{
${ }^{*}$ Research held at the Post-Graduate Program in Health Sciences Federal University of Rio Grande do Norte (UFRN) Level doctorate.
} 
death, the erosion of forgetfulness, and with a single act - the incision of a figure on a signboard of clay - the first anonymous writer has suddenly succeeded in all those seemingly impossible feats.

But writing was not the only invention that was created at the moment of that first incision, as the author highlights (1997, p.207), another creation happened at the same time: reading.

Writing and reading skills were quickly recognized as powerful ones. In the modern scientific world, where we noticed an increase in the number of researches, the scientific magazines play an important role, because they are dynamic ways to disseminate the knowledge that is produced.

The titles have a responsibility to document for posterity, each step expired in favor of the development of knowledge and to become available to the community concerned, the details of each done in laboratories or in field (Andrade, 2004, p.263).

Laville and Dionne (1999, p.247) claim that is in scientific journals that you will see better and faster the science that is done, it is in them that the community can evaluate the fair measure of the research, because the researcher needs say the essential, and conciseness, because the pages are limited

Currently, more than 600 thousand scientific journals are published around the world (Biojone, 2001), estimating that are written, daily, between six and seven thousand scientific papers to feed them (Trzesniak, 2001).

Indeed, the dentistry scientific production has exponentially grown in recent years. Cury (2004) states that between 2001 and 2003 there were more than scientific publications than throughout the twentieth century.

The fact is that magazines are read. The Instituto Brasileiro de Estudos e Pesquisas Socioeconômicos (INBRAPE) carried out a survey, in 2003, on the profile of dental surgeon, required by several entities, including the Federal Council of Dentistry (FCD) and the Brazilian Dental Association (BDA). The result indicated that $81.3 \%$ of dental surgeons say often read some dental journal.

By reflecting, critically, we noticed that the journals is not only the main purpose of establishing a bond of communication between professionals and students of dentistry; but also serves as a custodian of concepts that have been modelling, shaping and giving existence to the national dentistry.

Thus, we ask: what is the knowledge that is being produced and published in dentistry? Under questioning from this perspective, this study aimed tat carrying out an analysis of issues and topics addressed by three major dental journals during the period from 1990 to 2004 . These purposes were strengthened by 
reflections by Canoletti and Soares (2005, p.115) when warn that the analysis of literature can contribute to the evaluation of the course that the practice is taking at the same time in that can encourage criticism and the formulation of new projects.

\section{METHODOLOGICAL PROCEDURES}

This is a literature research with descriptive exploratory nature within a quantitative approach.

From number of magazines specializing in dentistry, and published in Brazil, we selected three, which are: the Magazine of the Brazilian Dental Association (ABO National),) and the Brazilian Dentistry Journal (RBO National ) Revista da published by Associação Paulista de Cirurgiões-Dentistas (APCD ABO / Section RJ.

The choice of these three magazines is justified by the fact that all were of general aspect, or reach a wide audience, ranging from clinical to the specialist and thus express more full production in dentistry. Besides the large print runs, they have regular national movement, recognized credibility and dental penetration in the middle.

A survey conducted by Amorim et al (2005, p.12), with the aim of analyzing, quantitatively, which dental journals are being consulted and read by dental surgeon, pointing these three magazines as the most cited.

The research of INBRAPE on the profile of the surgeon-dentist, it has noted that the most cited scientific journals, for that professional were: the APCD, the ABO and National RBO occupied, respectively, the first $(46.5 \%)$, the fourth $(9.6 \%)$ and seventh place $(4.2 \%)$.

Accordingly, these surveys confirmed the capability of the journals chosen to be object of our study.

It is worth stating that the three studied magazines are classified by Qualis by foundation CAPES (Coordenação de Aperfeiçoamento de Pessoal de Nível Superior) with B concept national. With these concepts, these journals do not meet all the criteria of impact, competitiveness and internationality as broadcast, now in the scientific world (Foratini, 1997). Still, this did not prevent from being as one of the most cited ones by dental surgeon, in surveys cited above.

We have worked for 15 years in the period from 1990 to 2004. As the National Journal ABO had its creation in 1993, thus, we studied it wholly. 
The total empirical material was formed by 246 copies, adding up the three magazines. We studied 90 copies of the Magazine APCD, as during the whole period that had its regular bimonthly publication. The magazine RBO, were 87 copies, as this was bimonthly publication in the year 1990 until the last issue, 2003. Since January 2004, this magazine has become as published quarterly, and the numbers 3 and 4 left together in a single copy. The National Magazine ABO is also bimonthly and contributed with 69 copies, as in the year of its creation (1993) was edited only 3 numbers.

In possession of each copy, it was completely checked and analyzed part of the empirical material various types of texts: scientific papers, cases, literature review work, journalistic material, interviews and articles of opinion. However, for purposes of the research, all of them named as articles. Our goal was to verify the themes addressed, not interested in the type of publication. The editorials did not take part of the research be4cause a single text, often emphasized on several areas and issues, making difficult qualify it in only one category.

Each article was classified by subject, by the title and keywords. When arose doubt, we accomplished a reading "floating" of the summary and / or the body of the text; this stage is what Gil (1999, p.85) named an exploratory reading of a literature research.

Many issues were objects of publication, and thus to end of analysis of empirical material, were established 25 thematic categories that emerged from the same material (table 1). It is worth highlighting that such categorization was submitted to the appreaciation and validation of two specialists in the area, who suggested some changes which were incorporated. These data were worked in Microsoft Excel 2001.

The data were recorded at three tables, one for each magazine. There, we recorded quantitatively the issues as they arose, as well as, in the lines, the amounts were prepared for each subject by clipping magazines during the time reviewed, and in columns, the general quantitative of all subjects available in magazines during each year of analysis, as tables 2, 3 and 4 .

Although the majority of thematic categories have been named according to the subjects that were inserted in them, it is appropriate to the detailing on some of them. About Basic Disciplines, was built by adding up the knowledge of anatomy, biology, physiology and microbiology. About Education / Training, in addition to this issue itself, we include the texts that dealt with publications and research. Bioethics was included in Ethics / Legal Dentistry. In Stomatology/ Pathology are also matters relating to semiology and diagnosis. The medical emergencies is part of Pharmacology/Therapy categories, as well as computers and 
laser integrate the New Technologies category. In Working Dentistry, we incorporate matters relating to ergonomics, and in Odontopediatrics, those relating to dentistry for babies. In Other Areas, we classified matters relevant to astrology, psychology, phonoaudiology, molecular biology, hypnosis, administration, marketing and quality policy. Themes such as, support staff in dentistry, conference and events, molecular dentistry, veterinary dentistry, dentistry and dentistry orthomolecular and sports dentistry have been included in the category Occupation, in addition to articles that dealt in a quite straightforward way about it. Parts of oral rehabilitation and bucomaxilofacial prosthesis were included in Prosthesis/Dental Materials. In general Health, issues like smoking, diabetes and AIDS. Finally, we must emphasize that in the cataloguing of the issues addressed by the revised National ABO, it has emerged the category Politics/Citizenship/Economy, which addressed these areas in a large way and without a direct connection with the dental area. Thus, we classify them separately and not include them in the category Other Areas.

\section{RESULTS}

Of the 246 issues analyzed, 2806 articles were classified and compounded the empirical material; these, 808 were from the National Magazine ABO, 856 of the APCD, and the 1142 RBO. After the classification and cataloguing of all articles, we have as an end result the data expressed in tables 1, 2, 3 and 4. 
Table 1 - Thematic Categories addressed by magazines, in the period from 1990-2004, in descending order, expressed in percentage

\begin{tabular}{|c|c|c|c|c|}
\hline \multirow{2}{*}{$\begin{array}{l}\text { THEMATIC } \\
\text { CATEGORIES }\end{array}$} & \multicolumn{4}{|c|}{ MAGAZINES } \\
\hline & $A B O$ & $A P C D$ & $R B O$ & Total\% \\
\hline Dentistry / Dental Materials & 11,63 & 10,75 & 17,86 & 13,41 \\
\hline $\begin{array}{l}\text { Public Health/ Preventive } \\
\text { Dentistry }\end{array}$ & 17,82 & 8,06 & 7,88 & 11,25 \\
\hline Endodontics & 6,93 & 8,65 & 18,13 & 11,24 \\
\hline Stomatology/Pathology & 9,78 & 9,81 & 7,27 & 8,95 \\
\hline Prosthesis / Dental Materials & 4,58 & 10,86 & 8,23 & 7,89 \\
\hline Periodontics & 2,72 & 7,94 & 6,57 & 5,74 \\
\hline Profession & 11,88 & 2,45 & 1,84 & 5,39 \\
\hline Surgery / Trauma & 2,60 & 8,06 & 3,50 & 4,72 \\
\hline odontopediatrics & 3,71 & 5,14 & 4,73 & 4,53 \\
\hline $\begin{array}{l}\text { Orthodontics / Orthopaedics } \\
\text { of Maxilares }\end{array}$ & 1,73 & 4,44 & 4,73 & 3,63 \\
\hline Pharmacology / Therapy & 2,10 & 3,16 & 2,89 & 2,72 \\
\hline Other areas & 7,05 & 0,58 & 0,53 & 2,72 \\
\hline Radiology / Imaginologia & 0,87 & 4,79 & 2,28 & 2,65 \\
\hline $\begin{array}{l}\text { DTM / ATM / Occlusion / } \\
\text { orofacial pain }\end{array}$ & 1,61 & 3,16 & 2,01 & 2,26 \\
\hline $\begin{array}{l}\text { Education / Training / } \\
\text { Research }\end{array}$ & 3,10 & 1,17 & 2,45 & 2,24 \\
\hline Implantodontics & 0,99 & 2,22 & 2,80 & 2,00 \\
\hline Ethics / Legal Dentistry & 2,23 & 2,10 & 1,49 & 1,94 \\
\hline Biosafety & 1,73 & 2,10 & 1,57 & $\mathbf{1 , 8 0}$ \\
\hline New Technologies & 1,73 & 1,05 & 0,61 & 1,13 \\
\hline General Health & 0,99 & 1,29 & 0,44 & 0,91 \\
\hline Work Dentistry & 0,87 & 0,82 & 0,96 & $\mathbf{0 , 8 8}$ \\
\hline $\begin{array}{l}\text { Policy / Citizenship / } \\
\text { Economics }\end{array}$ & 2,35 & - & - & $\mathbf{0 , 7 8}$ \\
\hline Patients with special needs & 0,50 & 0,70 & 0,53 & $\mathbf{0 , 5 8}$ \\
\hline Odontogeriatrics & 0,25 & 0,35 & 0,44 & $\mathbf{0 , 3 5}$ \\
\hline Basic Disciplines & 0,25 & 0,35 & 0,26 & 0,29 \\
\hline Total\% & 100,00 & 100,00 & 100,00 & 100,00 \\
\hline
\end{tabular}


Table 2 - Categories topics addressed by the National Journal ABO, in descending order, during 1993-2004

\begin{tabular}{|c|c|c|c|c|c|c|c|c|c|c|c|c|c|c|}
\hline ABO/Thematic categories & 1993 & 1994 & 1995 & 1996 & 1997 & 1998 & 1999 & 2000 & 2001 & 2002 & 2003 & 2004 & Total & $\%$ \\
\hline General health//Preventive dentistry & 8 & 32 & 6 & 8 & 12 & 19 & 11 & 8 & 12 & 5 & 10 & 13 & 144 & 17,82 \\
\hline Profession Dental Material & 4 & 9 & 6 & 6 & 7 & 12 & 7 & 6 & 5 & 14 & 12 & 8 & 96 & 11,88 \\
\hline Dentistry/Dental Materials & 1 & 8 & 11 & 7 & 4 & 11 & 8 & 7 & 8 & 10 & 12 & 7 & 94 & 11,63 \\
\hline Estomatology/ Pathology & 5 & 6 & 7 & 8 & 6 & 4 & 9 & 6 & 6 & 8 & 4 & 10 & 79 & $\mathbf{9 , 7 8}$ \\
\hline Other areas & 2 & 5 & 9 & 6 & 9 & 6 & 3 & 1 & 2 & 9 & 3 & 2 & 57 & 7,05 \\
\hline Endodontics & 2 & 5 & 6 & 6 & 7 & 2 & 5 & 4 & 9 & 3 & 2 & 5 & 56 & 6,93 \\
\hline Prosthesis / Dental Materials & 2 & 6 & 2 & 2 & 4 & 2 & 2 & 2 & 5 & 4 & 4 & 2 & 37 & 4,58 \\
\hline Odontopediatrrics & 1 & 3 & - & 2 & 2 & 3 & 1 & 4 & 5 & 4 & 1 & 4 & 30 & 3,71 \\
\hline Teaching/Education & 1 & 3 & 5 & 4 & 1 & - & 1 & 1 & - & 1 & - & 8 & 25 & 3,10 \\
\hline Periodontics & - & 3 & 2 & 1 & 1 & 2 & 4 & 4 & - & 3 & 1 & 1 & 22 & 2,72 \\
\hline Surgery / Trauma & 1 & 1 & 2 & 2 & 2 & 3 & 2 & 2 & - & 4 & 1 & 1 & 21 & 2,60 \\
\hline Policy / Citizenship / Economics & - & 2 & 3 & 3 & 4 & - & 1 & - & 1 & 2 & 3 & - & 19 & 2,35 \\
\hline Ethics / Legal Dentistry & - & 1 & 1 & 1 & 2 & 1 & 2 & 3 & 1 & 1 & 1 & 4 & 18 & 2,23 \\
\hline Pharmacology/ therapy & 1 & 1 & - & 1 & - & - & 3 & - & - & 3 & 5 & 3 & 17 & 2,10 \\
\hline Biosafety & 1 & - & 1 & 1 & 3 & - & - & 2 & - & 1 & 3 & 2 & 14 & 1,73 \\
\hline New technologies & 1 & 1 & 2 & 1 & 3 & - & 3 & 1 & - & - & 2 & - & 14 & $\mathbf{1 , 7 3}$ \\
\hline $\begin{array}{l}\text { Ortodontics/Orthopaedics of } \\
\text { Maxilares }\end{array}$ & 1 & 2 & 2 & 2 & 2 & 1 & 2 & - & 1 & - & 1 & - & 14 & 1,73 \\
\hline $\begin{array}{l}\text { DTM / ATM / Occlusion / orofacial } \\
\text { pain }\end{array}$ & - & 1 & - & 3 & 2 & 1 & - & 1 & 1 & 3 & 1 & - & 13 & 1,61 \\
\hline implantodonty & - & 1 & 1 & 1 & 3 & - & - & - & - & 2 & - & - & 8 & 0,99 \\
\hline General Health & - & - & 2 & - & 2 & 2 & - & 1 & - & - & 1 & - & 8 & 0,99 \\
\hline Radiology/Imaginology & 1 & 2 & 1 & - & - & - & - & - & - & - & 1 & 2 & 7 & $\mathbf{0 , 8 7}$ \\
\hline Working Odontology & - & - & - & 2 & - & - & 1 & 1 & - & - & 3 & - & 7 & $\mathbf{0 , 8 7}$ \\
\hline Patients with special needs & - & - & 1 & 1 & - & - & 1 & - & - & - & - & 1 & 4 & $\mathbf{0 , 5 0}$ \\
\hline Basic disciplines & 1 & - & - & - & - & - & - & - & - & - & 1 & - & 2 & 0,25 \\
\hline Odontogeriatry & - & - & - & 1 & - & - & - & - & 1 & - & - & - & 2 & 0,25 \\
\hline Total & 33 & 92 & 70 & 69 & 76 & 69 & 66 & 54 & 57 & 77 & 72 & 73 & 808 & 100 \\
\hline
\end{tabular}


Tabela 3 Thematic Categories addressed by the APCD Magazine, in descending order, during 1990-2004

\begin{tabular}{|c|c|c|c|c|c|c|c|c|c|c|c|c|c|c|c|c|c|}
\hline $\begin{array}{c}\text { APCD/ } \\
\text { THEMATIC/CATEGORIES }\end{array}$ & 1990 & 1991 & 1992 & 1993 & 1994 & 1995 & 1996 & 1997 & 1998 & 1999 & 2000 & 2001 & 2002 & 2003 & 2004 & Total & $\%$ \\
\hline Prosthesis / Dental Materials & 7 & 3 & 2 & 3 & 1 & 9 & 8 & 5 & 8 & 5 & 5 & 10 & 12 & 7 & 8 & 93 & $\mathbf{1 0 , 8 6}$ \\
\hline Dentostry/DentalMaterials & 6 & 8 & 4 & 3 & 4 & 5 & 7 & 6 & 8 & 6 & 4 & 5 & 4 & 12 & 10 & 92 & 10,75 \\
\hline Estomatology/Pathology & 6 & 4 & 4 & 3 & 3 & 4 & 3 & 8 & 2 & 7 & 7 & 6 & 9 & 10 & 8 & 84 & $\mathbf{9 , 8 1}$ \\
\hline Endodontics & 4 & 1 & 3 & 2 & 4 & 5 & 6 & 7 & 5 & 10 & 6 & 4 & 4 & 7 & 6 & 74 & 8,65 \\
\hline Surgery/Trauma & 7 & 4 & 2 & 2 & 3 & 2 & 5 & 7 & 8 & 5 & 3 & 3 & 4 & 7 & 7 & 69 & 8,06 \\
\hline $\begin{array}{l}\text { General Health/Preventive } \\
\text { Dentistry }\end{array}$ & 7 & 9 & 7 & 4 & 2 & 1 & 5 & 4 & 1 & 5 & 5 & 2 & 5 & 4 & 8 & 69 & 8,06 \\
\hline Periodontics & 3 & 6 & 2 & 2 & 9 & 2 & 4 & 4 & 5 & 4 & 4 & 5 & 5 & 5 & 8 & 68 & 7,94 \\
\hline Odontopediatrics & 4 & - & 2 & 2 & 3 & 4 & 2 & 3 & 2 & 4 & 1 & 5 & 2 & 7 & 3 & 44 & 5,14 \\
\hline Radiology/Imaginology & 3 & 2 & - & 2 & 1 & 1 & 4 & - & 1 & 3 & 4 & 6 & 4 & 6 & 4 & 41 & 4,79 \\
\hline $\begin{array}{l}\text { Ortodontics/ Orthopaedics of } \\
\text { Maxilares }\end{array}$ & - & - & 1 & - & 3 & 2 & 3 & 6 & 4 & 1 & 4 & 4 & 6 & 1 & 3 & 38 & 4,44 \\
\hline $\begin{array}{l}\text { DTM / ATM / Occlusion / } \\
\text { orofacial pain }\end{array}$ & - & 4 & 2 & 1 & - & 1 & 2 & 2 & 4 & 1 & 3 & 1 & 2 & 2 & 2 & 27 & 3,16 \\
\hline Profession & - & - & 1 & - & 1 & 3 & 1 & 3 & 3 & 1 & 2 & 2 & - & 2 & 2 & 21 & 2,45 \\
\hline Implantodonty & - & 1 & - & 2 & 1 & 1 & - & 1 & 1 & 1 & 2 & 2 & 3 & 3 & 1 & 19 & 2,22 \\
\hline Biosafety & 2 & 3 & 1 & 1 & - & 3 & - & - & - & 5 & 3 & - & - & - & - & 18 & 2,10 \\
\hline Ethics / Legal Dentistry & - & 1 & - & 2 & 1 & 2 & 2 & 2 & - & 1 & 1 & 1 & 1 & 1 & 3 & 18 & 2,10 \\
\hline General Health & - & - & - & 1 & 2 & - & - & - & - & 2 & - & 2 & 4 & - & - & 11 & 1,29 \\
\hline Teaching/Education & - & - & 1 & 1 & - & 1 & 2 & 2 & - & - & 1 & - & - & 1 & 1 & 10 & 1,17 \\
\hline New Technologies & - & 1 & - & 1 & - & - & 1 & 1 & 1 & - & 1 & - & 1 & 2 & - & 9 & $\mathbf{1 , 0 5}$ \\
\hline Working Dentistry & - & - & - & - & 2 & - & - & 1 & - & 2 & - & - & 1 & - & 1 & 7 & $\mathbf{0 , 8 2}$ \\
\hline Patients with special needs & - & - & - & - & - & - & 2 & - & - & - & - & 1 & 1 & - & 2 & 6 & $\mathbf{0 , 7 0}$ \\
\hline Other areas & - & - & 1 & - & - & 1 & - & - & 1 & - & - & - & 1 & - & 1 & 5 & $\mathbf{0 , 5 8}$ \\
\hline Basic Disciplines & - & - & - & - & - & - & - & 2 & - & - & - & - & 1 & - & - & 3 & $\mathbf{0 , 3 5}$ \\
\hline Odontogeriatrics & - & - & - & - & - & - & - & 1 & - & 1 & 1 & - & - & - & - & 3 & $\mathbf{0 , 3 5}$ \\
\hline Policy / Citizenship / Economics & - & - & - & - & - & - & - & - & - & - & - & - & - & - & - & - & - \\
\hline Total & 49 & 47 & 34 & 33 & 41 & 47 & 57 & 65 & 58 & 65 & 61 & 62 & 72 & 81 & 84 & 856 & 100 \\
\hline
\end{tabular}


Tabela 4-Thematic Categories addressed by RBO Magazine, in descending order, from 1990 to 2004

\begin{tabular}{|c|c|c|c|c|c|c|c|c|c|c|c|c|c|c|c|c|c|}
\hline $\begin{array}{c}\text { RBO/THEMATIC } \\
\text { CATEGORIES }\end{array}$ & 1990 & 1991 & 1992 & 1993 & 1994 & 1995 & 1996 & 1997 & 1998 & 1999 & 2000 & 2001 & 2002 & 2003 & 2004 & Total & $\%$ \\
\hline Endodontics & 9 & 10 & 4 & 11 & 9 & 15 & 16 & 22 & 22 & 15 & 18 & 20 & 16 & 12 & 8 & 207 & 18,13 \\
\hline Dentística/Dental Materials & 6 & 14 & 18 & 14 & 8 & 13 & 12 & 10 & 17 & 21 & 15 & 20 & 14 & 12 & 10 & 204 & 17,86 \\
\hline Prosthesis / Dental Materials & 5 & 6 & 9 & 8 & 3 & 7 & 6 & 10 & 3 & 4 & 6 & 6 & 8 & 10 & 3 & 94 & 8,23 \\
\hline $\begin{array}{l}\text { General Health/Preventive } \\
\text { Dentistry }\end{array}$ & 5 & 4 & 5 & 7 & 5 & 7 & 6 & 8 & 5 & 4 & 8 & 10 & 7 & 4 & 5 & 90 & $\mathbf{7 , 8 8}$ \\
\hline Estomatology/Pathology & 2 & 8 & 4 & 5 & - & 7 & 8 & 2 & 3 & 3 & 7 & 6 & 11 & 11 & 6 & 83 & 7,27 \\
\hline Odontopediatrics & 1 & 1 & 2 & 4 & 6 & 6 & 4 & 2 & 4 & 2 & 4 & 7 & 6 & 3 & 2 & 54 & 4,73 \\
\hline $\begin{array}{l}\text { Ortodontiy/ Orthopaedics of } \\
\text { Maxilares }\end{array}$ & 4 & 1 & 2 & 4 & 3 & 2 & 3 & 3 & 1 & 5 & 4 & 5 & 6 & 9 & 2 & 54 & 4,73 \\
\hline Surgery//Trauma & - & 4 & 1 & 2 & 4 & 2 & 1 & 4 & 4 & 3 & 2 & 3 & 2 & 7 & 1 & 40 & $\mathbf{3 , 5 0}$ \\
\hline Pharmacology/Therapy & 2 & 2 & 3 & 1 & - & 3 & 1 & 4 & 1 & 2 & 3 & 4 & 1 & 4 & 2 & 33 & 2,89 \\
\hline Implantodonty & - & 1 & - & 1 & - & - & 3 & 3 & - & 2 & 4 & 3 & 5 & 8 & 2 & 32 & 2,80 \\
\hline Teaching/Education & - & - & - & - & 1 & 1 & - & 1 & - & - & 3 & 5 & 6 & 7 & 4 & 28 & 2,45 \\
\hline $\begin{array}{l}\text { DTM / ATM / Occlusion / } \\
\text { orofacial pain }\end{array}$ & 4 & 1 & 2 & 2 & 2 & - & - & - & 2 & - & 2 & 2 & 4 & - & 2 & 23 & 2,01 \\
\hline Profession & - & - & - & - & - & - & - & 4 & - & - & 3 & 3 & 6 & 3 & 2 & 21 & 1,84 \\
\hline Biosafety & 1 & 1 & 3 & - & 3 & 1 & 1 & - & 1 & 1 & - & 2 & 1 & 2 & 1 & 18 & 1,57 \\
\hline Ethics / Legal Dentistry & 1 & - & - & - & - & - & 2 & - & 2 & - & 2 & 2 & 4 & 4 & - & 17 & 1,49 \\
\hline Working Dentistry & 1 & - & 1 & - & - & - & - & 1 & - & - & - & 1 & 4 & 2 & 1 & 11 & 0,96 \\
\hline New Technologies & - & 1 & - & - & - & - & - & 1 & - & - & 2 & - & - & 1 & 2 & 7 & $\mathbf{0 , 6 1}$ \\
\hline Other areas & - & - & - & - & 1 & - & - & 1 & - & - & 2 & - & 1 & - & 1 & 6 & $\mathbf{0 , 5 3}$ \\
\hline Patients with special needs & - & - & - & - & - & 1 & 1 & 1 & - & - & - & 1 & 1 & - & 1 & 6 & $\mathbf{0 , 5 3}$ \\
\hline Odontogeriatrics & - & - & - & - & - & - & - & - & - & - & 2 & 1 & - & 2 & - & 5 & 0,44 \\
\hline General Heath & - & - & - & 1 & - & - & - & - & - & 1 & 1 & - & - & 2 & - & 5 & 0,44 \\
\hline Basic Disciplines & 1 & - & - & - & - & - & 1 & - & - & - & - & 1 & - & - & - & 3 & $\mathbf{0 , 2 6}$ \\
\hline $\begin{array}{l}\text { Policy / Citizenship / } \\
\text { Economics }\end{array}$ & - & - & - & - & - & - & - & - & - & - & - & - & - & - & - & - & - \\
\hline Total & 46 & 57 & 58 & 63 & 48 & 69 & 75 & 84 & 74 & 69 & 94 & 110 & 114 & 118 & 63 & 1142 & 100 \\
\hline
\end{tabular}


By examining the tables 2, 3 and 4 which has recorded the general quantitative of scientific production of each of the magazines separately, and while conducting a crossing of the ten most cited thematic categories in all magazines are:

- National ABO X APCD: in 8 out 10 most referenced thematic categories has coincided. The differences are because the National ABO Tuesday treated more about issues relating to the categories Occupation and Other Areas, while the APCD, highlighted issues such as, Surgery / Trauma and Orthodontics / Orthopaedics of Maxilares.

- National ABO X RBO: in 9 out 10 categories has coincided. The differences are very similar in relation

to the APCD, or instead of Occupation and Other Areas, the RBO published about Pharmacology / Therapeutics and Orthodontics / Orthopaedics of Maxilares.

- APCD X RBO: we have nine coincidences among the ten most cited. The difference is that the APCD have emphasized more of Radiology / Imaginology while RBO highlighted about Pharmacology / Therapeutics.

\section{DISCUSSION}

The technique appears to be in the action of professionals. Thus, it supports the competence, as cautions Rios (2001, p.94). The author draws our attention to the fact the technical dimension to have its meaning impoverished, when is considered unlinked from other dimensions (aesthetics, ethics and politics). Thus, we have created a technical vision, in which overvalues the technique ignoring its place in a social and political context.

Thus, this essence of thought is reflected in the curriculum of guidelines of Dentistry courses, establishing a " humanist, critical, reflective and generalist training to serve in all levels of primary health care, based on technical and scientific rigor. It has become able to the the pursuit of activities relating to the oral health of population, guided into legal ethical principles, and understanding of the social, cultural and economic realities in his/her environment, leading the action for the transformation of reality for the benefit of society. " (Resolution CNE / ESC 3 / 2002).

The journals, object of our research, act disseminating the dental knowledge. They can thus help to spread knowledge in a more open way, within a complex and whole approach of life, just as urgent today, as Morin 
emphasizes (2000), or perpetuating the current trend dominant, where the focus is centralized in the biological and technical aspects, product of Cartesian and Newtonian view and is in paradigm of the Western world. The results, until up revealed, show that the dental learning tends to go more the second path.

Looking at the table 1, we observed that although the magazines have addressed various issues, there are other ones that were more present. This is clearly seen when we see that $52.73 \%$, or more than half of the items examined, are inserted in the first five thematic categories, which are in the majority, technical and biological aspects.

The preference for certain areas and in certain subjects is visible. Péret and Lima (2003, p.65) argue that the mercantilism view may be strengthening the traditional model, with emphasis on technicality and the private interest, influencing the research and training.

Within this same line of thought, Forattini (1996) warns that by continuing the current trend, the impact of scientific paper increasingly will be evaluated for compliance with the technological purpose, which is not always directed to the improvement of the life quality. Ponthieu (1995) complements this thinking, in saying that has increasingly noted the commercial character of technology.

We know that most research comes from Brazilian higher education. Paula and Bezerra (2003, p.10) assert that the dentistry teaching is adapted to an environment based on technical application, reflecting the strong presence of the dental equipment industry and dental materials. This model of education, geared toward to the work market, focusing on technical training, depends on the external knowledge and hinders the creation and universalization of appropriate solutions to the social and technological realities of country (Masetto, 1998).

Thus, our results assert the statements of these authors, since the areas of Dentistry/Dental Materials and Prosthesis / Dental Materials were present as themes in $21.30 \%$ of the articles listed.

In September 2004, the meeting of the Sociedade Brasileira de Pesquisa Odontológica (SBPqO) offered representative sample of the current Brazilian scientific production in dentistry, which is raw material for scientific journals in the field. In SBPqO, jobs are divided by area. According Andrade (2004, p.274), the area 5, which includes the disciplines of Dental Materials and Dentistry, was responsible for the largest number of submissions.

The high percentage of papers distributed in a few categories is also observed when we analyze each magazine separately. In ABO National, the first four categories add up 50.86\% of the papers published (table 2). 
The APCD presents 48.12 of the papers distributed in the five most present (Table 3). The RBO concentrates on four categories $52.10 \%$ of articles published in those fifteen years of study (Table 4).

The editor of the Brazilian Journal of Medical and Biological Research says that there is subjectivity in publishing and in the decisions about the choice of work for publication, although there are concrete and objective things that can be evaluated, and that the impact of the magazine depends on this type of objective and subjective decisions of editor (Greene, 1998).

Yamamoto (1999) also speaks in that sense, when he says that this selection, as a human enterprise, it is a difficult process that will be impartial, which is composed of subjective elements, leaving always the possibility of questioning. Besides, he complements the reasoning, it would be naive exposing (and cynical) deny that in the academic world, other parameters, in addition to the merits, place themselves between the production of knowledge and its appearance in periodic focus.

This point of view is also addressed by Herzberg during interview by Andrade (2004, p.269). He says that the editor should know the current frontiers of science to make sure of the areas that are arousing greater interest. And he also asserts, saying that if there is a lot of activity in a specific field, this work can be cited more frequently and quickly. And it adds: the publisher can not succumb to what he called the "neurosis by novelty," namely, the lack of vision in the critical enthusiasm to publish such a novelty.

Chauí (2000) states that are experiencing a loss of autonomy and responsibility in the generation of new knowledge, because the use of scientific results has not been determined by researchers and nor by the public power. The researches are being developed for private purposes, with the abandonment of social responsibility. Thus, these reflections and discussions show us that the ethical responsibilities of scientists, the professionals in the area of health and responsible people in disseminating the knowledge is much higher and should be evaluated not only for exercise and results of researches or technical actions, and surgical clinics itself, but also meanly by social consequences arising from them, contributing to the improvement in quality of life.

Thus, making an analogy of the space occupied by the various issues and topics in magazines with the provisions in these in curriculum of courses in Brazilian dentistry, we saw similarities. Paula and Bezerra (2003), in research on the structure of the curriculum courses of Dentistry, report that the relevant treatment given to the technical training is real, and the visible separation between the areas of vocational training and basic education. In 
the same survey was observed that the treatment of those areas, such as public health, ethics and citizenship, it is very different, dependent on the profile that each course wishes to conceive for its students.

We believe that this last remark is also valid when it comes from magazines, or to choose which path is pursued free, a fact we notice when we analyze the profile of each.

Despite being those of general character and look like fairly, with regard to their presentations and formats - even in terms of percentage of the issues they raised - we believe that the ABO National has some peculiarities, such as more newspaper news, interviews and opinions for the other two. It may seem that these paper formats have greater "freedom" to address issues "no dentist," issues that are important and diverse interests, which are not usually spoken and treated in papers of scientific research in health, as economy, politics, citizenship and other areas of knowledge, but that end up acting positively to the construction of a more integral dentistry.

The ABO National Journal is published by the Brazilian Association of Dentistry, and thus ends up serving as the spokesperson of that entity that unites the majority of professionals in the area. This fact can justify the high percentage of papers(11.63\%) which deal with the occupation, result that diverged the other two magazines.

The thematic category Public Health/Preventive Dentistry also highlighted much in the magazine, which has resulted in this category was the second in general. This area has a strategic role in dentistry as it is identified as an area for discussion of political and social issues inserted in health (Amorim, 2002).

However, it is important to stress that, despite this positive result on this category, I noticed that the majority of the issues addressed in papers that area focused on technical contents, and quite coupled to dentistry, for example, epidemiological surveys, programs, oral health and fluoridation. As to the examination of the qualitative content of the categories, although was not subject of this investigation, our brief observation points out to the results found by Narvai (1997) on the Brazilian scientific production in the area of Social and Preventive Dentistry.

On Education/Training Category was, in general, less present in the publications of magazines, this worrying fact, since we do not conceive the researches, discussions in dentistry walking separated of education and, especially, not reflecting on the same. In our view, this issue deserves more emphasis.

It is important to draw attention to the little space that occupied the area of ethics, which was inserted in conjunction with the Legal Dentistry, as a cross-cultural theme in any area of knowledge, particularly health. In the current context, discussions and reflections on that theme assume a high significance, considering its importance in 
the face of the diversity of problems presented in the model of society in which we live, such as hunger, poverty, violence, racism, social exclusion disrespect to the environment, among many others, that violate their lives. Therefore, this consideration becomes essential vocational training, whatever the area of education, especially the health area.

If there are no changes in ways of designing and teaching the dentistry, we take the risk of perpetuating a career under the aegis of a highly technical education(Nash, 1998; Baum, 1997), and without the necessary expression in the context of health professions. This trend has been observed in studies involving the collection of data on the dental profession (Hallissey et al, 2000; Chambers, 2001; Skelly and Fleming, 2002).

Baum (2003) states that the status maintenance of the profession is undoubtedly related to their ability to absorb knowledge and technology, enabling a real improvement of the life quality of people. And, within this same thought philosophy, Campanário (1999) highlights that the scientific education should provide basic elements to the understanding of the reality that surrounds us, but also for understanding the role of science in our society.

\section{CONCLUSIONS}

Although the journals analyzed are general and addressing issues of multidisciplinary, it became clear that there are issues that predominate in its themes, these subjects that correspond in the majority of the technical disciplines of highly professional aspect.

It worth highlighting that reflections on ethics, which contribute to a complex, critical and reflective view of reality, providing changes in dentistry making are less addressed and disclosed. Besides, teaching and education are not covered as they should, so that we could rebuild the dentistry being and making within more compatible principles with the new curriculum guidelines for dentistry.

By relating therefore the results of this research, with the curricular structure of the courses of Brazilian dentistry, we observed that the issues addressed in magazines seem to obey to a similar provision to that occupied by related disciplines in the field of training, i.e. greater emphasis and space given to technical and vocational areas.

Thus, we understood that the mercantilist model, fragmentation of knowledge, together with a vision of the positivist and Cartesian of reality, leave us to lose sight of the global issues and holistic sense of man. Therefore, we believe that the way as dentistry is being designed and structured, often has antagonized with the search for new professional profile of this area, geared toward a generalist, humanist, critical and reflective conception, as the 
resolution sets CNE / CES 3 / 2002 of the New Curriculum Guidelines for graduate courses in dentistry. At the same time, has contributed to the construction of a science without soul, which has become the inhuman and banal life, as we are drawn attention by Morin (2000).

Indeed, it is worth emphasizing increasingly that the journals serve as a link in scientific communication between professionals and students and is considered important vehicles for the generation of new knowledge, and directly influencing the dentistry practice and education, but also leaving it is influenced by these.

In short, communication exerted by scientific journals should help improve the quality of life and life in society, since it will influence and guide the thoughts, reflections and attitudes, shaping the making in all fields of knowledge. We must bear in mind that this is the social function of journals.

Thinking more as a science is done and how understand it in the deepest sense, they have become complex tasks. Thus, this research sought to contribute to the understanding of the characteristics of the process of dentistry knowledge production, however, we see that it is a need for a qualitative deepening of the study, with the aim of increasing the viability of analysis to investigate in what stage is each area of knowledge in dentistry. Even in face of their limitations, the results seem to offer subsidies for reflection, as well as for subsequent studies on the subject, serving as a parameter to monitor the evolution of dental thinking.

\section{BIBLIOGRAPHICAL REFERENCES}

1. AMORIM, K. P. C. Nos labirintos da vida: A (bio)ética na formação de odontólogos (a visão de docentes). 2002. Dissertação (Mestrado) - Faculdade de Odontologia, Universidade Federal do Rio Grande do Norte, Natal.

2. AMORIM, K. P. C.; ALVES, M. C. F.; GERMANO, R. M. A construção do conhecimento na odontologia: a produção científica em debate. Acta Cirúrgica Brasileira, v.20, Supl 1, p.12-15, 2005.

3. ANDRADE, M. Publicações. ABO Nac, v.12, n.5, p. 262-75, 2004.

4. BAUM, B. J. The absence of a culture of science in dental education. A North American perspective. Eur J Dent Educ, v.1, n.1, p. 2-5, 1997.

5. BAUM, B. J. Can biomedical science be made relevant in dental education? Eur J Dent Educ, v.7, n.2, p. 49$55,2003$.

6. BIOJONE M. R. Forma e função dos periódicos científicos na comunicação da ciência. 2001. Dissertação (Mestrado) - Escola de Comunicação e Artes, Universidade de São Paulo, São Paulo.

7. CAMPANARIO, J. M. La ciencia que no enseñamos. Enseñanza de las Ciencias, v.17, n.3, p.397-410, 1999. 
8. CANOLETTI, B.; SOARES, C. B. Programa de prevenção ao consumo de drogas no Brasil: uma análise da produção científica de 1991 a 2001. Interface - Comunic., Saúde, Educ., v.9, n.16, p. 115-29, 2005.

9. CHAMBERS, D. W. The role of dentists in dentistry. J Dent Educ, v.65, n.12, p. 1430-1440, 2001.

10. CHAUÍ, M. Escritos sobre a universidade. São Paulo: Ed. Unesp, 2000.

11. CONSELHO NACIONAL DE EDUCAÇÃO. Diretrizes Curriculares nacionais do curso de graduação em odontologia, Resolução CNE/CES 3/2002, Diário Oficial da União, Brasília, 4 de março de 2002, Seção 1, p. 10 .

12. CURY, J. A. The evolution of dental research in Brazil. Braz. oral res., v.18, n.2, p.97, 2004.

13. FORATINI, O. P. A tríade da publicação científica. Rev Saúde Publica, v.30, n.1, p. 101-111, 1996.

14. FORATINI, O. P. A internacionalidade da ciência. Rev Saúde Publica, v. 31, n.2, p.115, 1997.

15. GIL, A. C. Métodos e Técnicas de Pesquisa Social . São Paulo: Atlas, 1999.

16. GREENE, L. J. O dilema do editor de uma revista biomédica: aceitar ou não aceitar. Ci. Inf., v. 27, n.2, p.230$232,1988$.

17. HALLISSEY, J.; HANNIGAN, A.; RAY, N. Reasons for choosing dentistry as a career - a survey of dental students attending um dental school in Ireland during 1998-99. . Eur J Dent Educ, v.4, n.2, p. 77-81, 2000.

18. INBRAPE - INSTITUTO BRASILEIRO DE ESTUDOS E PESQUISA SÓCIO-ECONÔMICOS. Perfil do cirurgião-dentista no Brasil. 2003. Disponível em: 〈http://www.cfo.org.br/download/pdf/perfil_CD.pdf〉. Acesso em: 18 jan. 2004.

19. LAVILlE, C.; DIONNE, J. A construção do Saber: manual de metodologia da pesquisa em ciências humanas. Porto Alegre: Ed. UFMG, 1999.

20. MANGUEL, A. Uma história da leitura. São Paulo: Companhia das Letras, 1997.

21. MORIN, E. Ciência com Consciência. Rio de Janeiro: Bertrand Brasil, 2000.

22. NARVAI, P. C. Produção científica na área de odontologia preventiva social. BRASIL, 1986-1993. 1997. Tese (Doutorado) - Faculdade de Saúde Pública, Universidade de São Paulo, São Paulo.

23. NASH, D. A. “And the band play on...”. J Dent Educ, v. 62, n. 12, p. 964-967, 1998.

24. PAULA, L M.; BEZERRA, A. C. B. A estrutura curricular dos cursos de Odontologia no Brasil. Revista da ABENO, v.3, n.1, p. 7-14, 2003.

25. PÉRET, A. C. A.; LIMA, M. L. R. A Pesquisa e a formação do professor de odontologia nas políticas internacionais e na educação. Revista da ABENO, v.3, n.1, p. 65-69, 2003. 
26. PONTHIEU, E. Comment évaluer l'impact économique des grands programmes? La Recherche (Suppl 276), p. $12-15,1995$.

27. RIOS, T. A. Compreender e ensinar: por uma docência da melhor qualidade. São Paulo: Ed. Cortez, 2001.

28. SKELLY, A. M.; FLEMING, G. J. Perceptions of dental career among successful applicants for dentistry compared with those of fifth-year dental students. Prim Dent Care, v.9, n.2, p. 41-46, 2002.

29. TRZESNIAK, P. A. Concepção e a construção da revista científica. In: Curso de Editoração Científica. Petrópolis: ABEC; 2001. p.17-23

30. YAMAMOTO, O. H.; SOUZA, C. C.; YAMAMOTO, M. E. A produção Científica na Psicologia: uma análise dos Periódicos Brasileiros no período 1990-1997. Psicol., Reflex. Crít., v. 12, n.2, 1999.

Disponível em: <http://www.scielo.br/scielo.php?script=sci_issuetoc\&pid=0102797219990002\&lng=pt\&nrm=iso > Acesso em: 04 dez. 2004. 